\title{
O ESPAÇO PÚBLICO NA CONTEMPORANEIDADE E NO FUTURO: O UTOPISMO QUANDO APLICADO
}

\author{
PUBLIC SPACE NOWADAYS AND IN THE FUTURE: APPLIED UTOPIANISM
}

\author{
EL ESPACIO PÚBLICO EN LA CONTEMPORÁNEA Y EN EL FUTURO: UTPISMO APLICADO
}

\section{RESUMO}

Introdução: Na contemporaneidade, o espaço público urbano, mais precisamente: as ruas, calçadas, parques e praças, por muitas vezes, têm seu uso e funções subutilizadas, conflituosas, predominando o desvio de função, o medo e a diferença em contraponto ao espaço público autêntico, ou seja, aquele de livre acesso, tanto físico, quanto simbólico. Com a popularização do automóvel, com o aumento da violência e com a baixa qualidade formal e funcional do espaço público contemporâneo, temos uma problemática em curso, ou seja, espaços públicos que já não cumprem sua função. Objetivo: Dessa forma, visando maximizar seu uso e reduzir seus conflitos, propomos como objetivo refletir sobre os estudos desenvolvidos acerca do espaço público ideal e utópico. Para tanto, levantamos os seguintes questionamentos: a) o que é um bom espaço público? b) o que visa um espaço público utópico? c) o que vem sendo idealizado e já implantado? Metodologia: Nosso aporte metodológico teve por base a pesquisa bibliográfica. Resultados: Dentre os resultados, destacamos que no utopismo a coexistência (sociocultural, ambiental e entre modais de transportes) constitui a sua principal característica. Já o bom espaço público é aquele capaz de despertar o desejo de permanência de seus usuários. Conclusão: $O$ espaço público utópico demandará impactante mudança socioespacial em nossas cidades, considerando novas mobilidades, energias alternativas, recriação da paisagem primária e, principalmente, primar pela coexistência.

Palavras-chave: Espaço Público. Utópico. Coexistência. Cidade.

\section{ABSTRACT}

Introduction: Nowadays, urban public space, more precisely the streets, sidewalks, parks and squares, many times have their usage and functions underused, conflicted, outstanding a function deviation, fear and difference contrasting with the authentic public space, we free access, both physical and symbolical. With the popularization of the automobile, violence and the low quality - either formal or functional - of the contemporary public space, we have an ongoing problem, that is, public spaces that no longer perform their functions. Objective: Thus, aiming at maximizing its usage and reducing its conflicts, we present reflections about studies developed on the ideal and utopian public space. For that, we raise the following questions: a) what is a good public space? b) what is the aim of a utopian public space? c) what have been idealized and already implanted? Methodology: Our methodological support was based on bibliographical research. Results: Among the results, we highlight that coexistence (sociocultural, environmental and of transport modes) is the main characteristic of utopianism. In addition, a good public space is that one which promotes the desire of permanence among its users. Conclusion: The utopian public space will demand an impacting socio-spatial charge in or cities, considering new modalities alternative energies, recreation of the primary landscape and, above all, excelling for coexistence.

Keywords: Public Space. Utopian. Coexistence. City.

\section{RESUMEN}

Introducción: En la época contemporánea, el espacio público urbano, más precisamente: calles, aceras, parques y plazas, muchas veces tienen su uso y funciones infrautilizadas, conflictivas, predominando la desviación de función, el miedo y la diferencia en contrapunto al espacio público auténtico, es decir. , el de libre acceso, tanto físico como simbólico. Con la popularización del automóvil, con

\section{Anderson Franciscon ${ }^{a}$ Marcos Clair Bovo ${ }^{a}$}

a Universidade Estadual do Paraná (UNESPAR), Campo Mourão, PR, Brasil

DOI: 10.12957/geouerj.2021.45132

Correpondência: mcbovo@yahoo.com

Recebido em: 9 set. 2019 Aceito em: 22 ago.2021 
el aumento de la violencia y con la baja calidad formal y funcional del espacio público contemporáneo, tenemos un problema permanente, es decir, espacios públicos que ya no cumplen con su función. Objetivo: Así, con el objetivo de maximizar su uso y reducir sus conflictos, proponemos como objetivo reflexionar sobre los estudios desarrollados sobre el espacio público ideal y utópico. Por tanto, nos planteamos las siguientes cuestiones: a) ¿Qué es un buen espacio público? b) ¿A qué apunta un espacio público utópico? c) ¿Qué se ha idealizado y ya implementado? Metodología: Nuestro aporte metodológico se basó en la investigación bibliográfica. Resultados: Entre los resultados, destacamos que en el utopismo, la convivencia (sociocultural, ambiental y entre modos de transporte) es su principal característica. Un buen espacio público, en cambio, es capaz de despertar el deseo de permanencia de sus usuarios. Conclusión: El espacio público utópico demandará un cambio socioespacial impactante en nuestras ciudades, considerando nuevas movilidades, energías alternativas, recreando el paisaje primario $y$, sobre todo, luchando por la convivencia.

Palabras-clave: Lugar público. Utópico. Coexistencia. Ciudad. 


\section{INTRODUÇÃO}

Desde a Utopia de Thomas Morus em 1516, autores como Robert Owen, Saint Simon, Charles Fourier, Ebenezer Howard e Le Corbusier têm se dedicado a estudos utópicos voltados às cidades, sempre levando em consideração as fraquezas momentâneas e imaginando as condições melhores para o futuro, no caso das cidades e dos espaços públicos urbanos, sempre visando combater a alienação, a pobreza, as falhas seculares, os problemas ambientais e, ao mesmo tempo, alimentando um sonho de cidade ideal.

Nas palavras de Sampaio (1996, p. 55-56), “[...] a cidade ideal aparece [...] como a superação da cidade real, cheia de equívocos e erros de toda a ordem, incorporando uma espécie de visão maniqueísta de mundo, reduzindo a realidade a uma condição dualista entre algo ideal (o bem) e algo real (o mal)". Dessa forma, a cidade ideal é vista como uma solução, um espelho para a cidade real, na qual os equívocos históricos (seculares, sociais, religiosos) devem ser mitigados em busca de uma cidade ideal, do ponto de vista social, cultural, ambiental e econômico, proporcionando salubridade e coexistência entre seus cidadãos.

Nesse sentido, o movimento utopista ganhou força no século XVIII devido às condições precárias da cidade industrial (alta densidade, jornada de trabalho elevada, insalubridade e urbanismo precário), em busca de uma sociedade ideal. Grandes utopistas trouxeram significativas discussões, como Robert Owen (1771 1858) - plano urbanístico completo, integrando política e economia; Saint Simon (1760-1825) - sociedade para a classe trabalhadora; Charles Fourier (1772 - 1825) - Falanstério, edifício único com a função de abrigar todas as atividades da cidade; Ebenezer Howard (1850-1928) - Cidades Jardins; Le Corbusier (1887-1965) Cidade radiante, entre outros.

É importante destacar a relação entre espaço público, cidade e sociedade, de maneira que nessa relação, possamos entendê-los como espaço plurifacetado, ou seja, o local da diversidade, tanto conceitual, quanto funcional e simbólico, de modo que o espaço público urbano possa representar a imagem e/ou a própria cidade; ser simbólico; resguardar a memória; palco da ação política, liberdade e democracia; local de livre comunicação e por fim, elemento capaz de moldar a cultura e o biótipo humano. Para tanto, as citadas características integram o espaço público autêntico que ainda deve ser o local da diversidade de agir e ser visto, de aclamar por direitos públicos, memorizar personagens e incidentes importantes. Ainda se entende que o espaço público autêntico deve pertencer ao Estado e proporcionar seu livre acesso. Assim, o espaço público se caracteriza como importante elemento da cidade, muitas vezes sendo considerado como a própria cidade. É relevante destacar a diversidade de espaços públicos existentes, no entanto utilizamos como recorte o parque, a praça, a rua e suas calçadas adjacentes. 
Muito frequentado entre o fim do século XIX e início do século XX, o espaço público tem seu declínio acentuado na segunda metade do último século, período em que há redução do espaço pedonal em prol do automóvel; surgimento dos espaços publicizados (espaços privados com características públicas, como shopping center e parques de diversões), aumento da violência e consequente descaso do poder público. Nesse contexto, o espaço público urbano perde seu prestígio, sua essência e sua funcionalidade, por muitas vezes sendo considerado como "peso morto" para o Estado, consequentemente tornando-se um não-lugar. Entende-se como "não-lugar" o local no qual o cidadão não estabelece vínculos e sentimentos, não sentido vontade em permanecer por mais tempo além do necessário.

Assim, temos uma problemática em curso, pois os espaços públicos passam a ser subutilizados, não atendendo mais aos anseios do cidadão contemporâneo, tão pouco cumprindo sua funcionalidade junto ao plano urbanístico da cidade. Dessa forma, torna-se necessário que estudemos o espaço público contemporâneo, analisando suas deficiências e potencialidades por meio de um olhar utópico, assim propondo novos espaços públicos, visando atender o homem contemporâneo com pensamento nas gerações futuras.

Uma visão futurística torna-se importante para compreender o presente e idealizar o futuro. Assim, Para Boyer (1994), o telespectador, no caso, o usuário não deve estar apenas em contato permanente com o mundo realístico, é desejável que haja contato com os pensamentos utópicos, de forma a gerar um olhar crítico, produzindo assim, uma disposição para mudanças sociais. Nesse sentido, segundo Bauman (2007), para nascer sonhos utópicos devem coincidir duas hipóteses, a primeira defende a existência de algo errado, enquanto a segunda, trata-se da confiança humana em equacionar tal problemática. Bauman (2007) defende que sem as utopias de outrora, o homem ainda moraria em cavernas, num contexto miserável e nu. Para o autor, são os sonhos que trazem o progresso, sendo assim as utopias tendem a proporcionar o progresso.

Amplamente explorado em macroescala, tendo a cidade como objeto de estudo, o utopismo pouco se aplica na especificidade do espaço público urbano. Muito vagamente, há estudos teóricos e práticos utilizando-se de ideais mais próximos de nossa realidade. Dessa forma, o aporte metodológico foi constituído de estudos teóricos, tendo por base a revisão de literatura (livros; artigos; e sites de estúdios de arquitetura), objetivamos apresentar estudos acerca do espaço público ideal, respondendo as seguintes incógnitas: O que é um bom espaço público? O que visa um espaço público utópico? O que vem sendo idealizado e já implantado a curto, médio e longo prazo, ou seja, nos próximos cem anos?

O espaço público tem se mostrado metamórfico ao longo de sua história, tanto em seus quesitos espaciais, quanto funcionais. À medida que a sociedade se desenvolve, consequentemente, modifica suas atividades culturais: das simples vias estreitas da cidade medieval (trafego de pessoas, animais e carroças) ao imponente Eixo Monumental de Brasília (250 metros de largura), destinado ao tráfego de automóveis; das 
praças e parques voltados ao lazer contemplativo às praças e parques contemplando lazer ativo, contemplativo e comercial.

Nesse contexto, entendemos que a função socioespacial dos espaços públicos se modificam à medida que a sociedade se transforma. Sendo assim, torna-se importante discorrer sobre o espaço público atual e suas qualidades desejadas no presente e futuro. Diante disso, organizamos essa parte em três tópicos com objetivo de facilitar a compreensão do leitor.

\section{O ESPAÇO PÚBLICO IDEAL: CARACTERÍSTICAS DESEJADAS DE UM BOM ESPAÇO PÚBLICO}

Iniciamos esse tópico questionando: O que é um bom espaço público? Trata-se de uma abordagem subjetiva, visto que cada indivíduo possui anseios distintos. Até mesmo para os estudiosos, o bom espaço público assume caráter distinto.

Para Le Goff (1998), o bom espaço público deve ser dinâmico, estando em constante mutação e em consonância com a sociedade. Enquanto que para Calliari (2016), o espaço público deve proporcionar permanência e estimular encontros. De caráter mais complexo, para Whyte (2004), esse espaço deve conter sol, sombra, ventos, árvores, fontes de águas, bancos, mesas e comidas. Assim, entra em cena a dinamicidade, a diversidade, a presença de água, refeições e os condicionantes atmosféricos.

Diante de tal subjetividade, afinal, o que é um bom espaço público? A resposta para Calliari (2016, p.57), “[...] está ligada à qualidade do espaço público em relação à qualidade da experiência humana que nele se dá”, assim: "[...] A "régua” a ser usada nessa medição é a capacidade dos espaços públicos de proporcionar o encontro e estimular as pessoas a permanecer por mais tempo nele".

Com base na literatura existente, dentre as principais características desejadas em um bom espaço público, podemos destacar: significado, legibilidade, diversidade, escala humana, espírito de vizinhança e flexibilidade. Nesse contexto, isoladamente as citadas características não constituem um bom espaço público, mas sim, constitui aspectos desejados. Ainda para que um espaço público seja agradável, o citado conjunto deve manter uma sintonia entre si, sociedade e poder público. A seguir, descreveremos a importância de cada aspecto mencionado.

Dessa forma, Calliari (2016) evidencia que o espaço público deve apresentar significado, ou seja, é o espaço vivido, aquele que dá sentidos para as pessoas que o utilizam. Esses sentimentos fazem do espaço um lugar que apresenta segurança a seus frequentadores. Ainda deve apresentar legibilidade, ou seja, é preciso que o homem conheça e entenda o espaço que frequenta. "[...] Tão mais confortável é a cidade quanto mais ela é reconhecível pelos seus habitantes" Calliari (2016, p.62). No mesmo sentido, Lynch (2014) destaca que 
a legibilidade cria um mapa mental ligando passado e presente. A ligação entre passado e presente não representa necessariamente uma larga escala cronológica, pois o antes e o depois, no melhor sentido: conheço esse lugar, já passei por aqui á 30 minutos, ou no mês passado.

Para Calliari (2016) e Jacobs (2014), a diversidade funcional deve proporcionar vida ao espaço público, sendo que este espaço deve ser frequentado por diferentes grupos sociais, em diferentes horários do dia. Assim, permanecendo sempre frequentado. Já Daroda (2012, p.31) complementa os ideais dos autores anteriores ao destacar as características que asseguram "a vitalidade urbana, em termos sociais" por meio "da troca interpessoal e intergeracional, mas também em termos econômicos, por garantir a sustentabilidade entre os usos".

A diversidade funcional garante a utilização do espaço público em diferentes horários, enquanto o comércio tradicional proporciona a utilização do espaço público em horário comercial, os barzinhos noturnos proporcionam a utilização do espaço público em horário noturno. Feiras, práticas desportivas e demais atividades culturais podem dar utilização ao espaço público aos finais de semana e feriados.

Já a escala humana é o ambiente feito para o homem, sendo propício a um bom espaço público, assim sendo, Calliari (2016) destaca que o espaço deve favorecer a usabilidade, contendo sombra, quadras curtas, bancos, bebedouros, além de favorecer os passeios pedonais, ver, ouvir e falar. Essa relação espaço público/entorno ou "espírito de vizinhança" é relevante para a vitalidade e mantimento do espaço público. Dessa forma, o bom espaço público objetiva ao homem "sentir e vivenciar" o espaço, sentir-se como integrante do espaço público, desfruindo do conforto ambiental (lumínico, acústico, intempéries) e também ergonômicos.

As softedges (lojas, residências, bares) vizinhas acabam por proporcionar atratividade, ao mesmo tempo segurança, pois os lojistas zelam pelo bom uso do espaço público. A importância do espírito de vizinhança para a rua e demais espaços públicos são retratados por Jacobs (2014, p. 48), "[...] a inexistência dessa confiança é um desastre para a rua. Seu cultivo não pode ser institucionalizado. E, acima de tudo, ela implica não comprometimento pessoal". A confiança citada por Jacobs implica na relação entre espaços públicos e demais espaços adjacentes. O espaço público não deve ser visto e nem funcionar como uma ilha, mas sim, se integrar com o entorno. A integração faz com que as atividades não ofertadas nos espaços públicos passem a compôlos por meio da oferta do setor privado.

As softedges representam muito mais que uma diversidade de atrações, tais comércios também implicam na manutenção, limpeza e segurança do espaço público. Os próprios lojistas acabam por limpar, zelar, fiscalizar e garantir a segurança do espaço público, por meio da presença de pessoas e por muitas vezes sistemas de segurança como câmeras. 
Para Whyte (2001), a flexibilidade funcional permite que um usuário utilize o espaço da forma que Ihe agrade, não de forma imposta. Em um campo aberto como um campo de futebol podemos praticar tal desporto, no entanto, também é possível a realização de piquenique e/ou outras atividades. Corroborando com o autor, Daroda (2012) pontua que esses espaços flexíveis proporcionam os desejos dos usuários quanto à utilização dos mesmos. Assim, a apropriação dos espaços públicos livres, isto é, os espaços sem elementos construídos devem demonstrar as necessidades e também as carências existentes nos lugares mais abertos, indicando as possibilidades de uso comum para a população. Ainda, citamos que as características descritas devem impactar positivamente nas atividades sensoriais humanas, de modo a confortar e proporcionar prazer, conforme Gehl (2016).

Segundo Gehl (2016), proteger abrange: proteção contra acidentes e sensação de segurança (proteção aos pedestres e eliminar o medo do tráfego); proteção contra crimes e violência, sensação de segurança (ambientes públicos cheios de vida; olhos da rua; sobreposição de funções de dia e noite; boa iluminação) e proteção contra experiências sensoriais desconfortáveis (vento, chuva/neve, frio/calor, poluição e poeira, barulho e ofuscamento).

Já o conforto abrange a oportunidade para caminhar (espaço para caminhar; ausência de obstáculos; boas superfícies; acessibilidade para todos e fachadas interessantes); oportunidade para permanecer em pé (efeito de transição/zonas atraentes para permanecer em pé/ficar e apoio para pessoas em pé); oportunidades para sentar-se (zonas para sentar-se; tirar proveitos das vantagens vistas, sol, pessoas; bons lugares para sentar-se; bancos para descanso); oportunidades para ver: (distâncias razoáveis para observação; linhas de visão desobstruídas; vistas interessantes. Iluminação: (quando escuro). Oportunidade para ouvir e conversar: (baixos níveis de ruído; mobiliário urbano com disposição para paisagens/conversas). Oportunidade para brincar e praticar atividades físicas: (convites para a criatividade, atividade físicas, ginástica e jogos; durante o dia e à noite; no verão e no inverno).

Quanto ao último princípio pontuado pelo autor, o prazer apresenta a escala (edifícios e espaços projetados de acordo com a escala humana); oportunidade de aproveitar aspectos positivos do clima (sol/sombra; calor/refrescar; brisa); experiências sensoriais positivas (bom projeto e detalhamento; bons materiais; ótimas vistas; árvores, plantas e água).

Assim sendo, o bom espaço público deve proporcionar a seus usuários prazer, conforto e proteção. É necessário que o homem domine e prevaleça sobre o local e dessa forma, "à medida que o homem aumenta o seu poder sobre a natureza, diminui o medo que sente dela" Tuan (2005, p. 16). Por fim, entendemos que o bom espaço público é aquele que se apresenta como um chamariz, ou seja, trata-se de um espaço atrativo à sociedade, ao mesmo tempo, oferecendo condições satisfatórias à permanência dos frequentadores. Tal permanência é proporcionada pelo conjunto harmônico entre espaço, homem e atividades culturais possíveis 
de se exercer. Para tanto, entendemos que o bom espaço público trata-se de um atributo desejado na contemporaneidade, assim como também para as gerações futuras. Sendo assim, nos próximos tópicos vamos tecer algumas reflexões já planejadas em curto e em médio prazo.

\section{O ESPAÇO PÚBLICO, TRANSFORMAÇÕES AO NOSSO ALCANCE IMEDIATO}

Devido à relevância histórica-funcional, na contemporaneidade os espaços públicos apresentam problemas tanto em sua utilização, quanto em sua função, como: apropriações e privatizações, conflitos entre grupos étnico-culturais, abandono, presença constante e onipresente do medo, além do mais, surge a "concorrência" dos espaços privados publicizados (shoppings, parques, estádios, entre outros). O panorama citado faz do espaço público contemporâneo subutilizado.

Nesse contexto, os espaços públicos como a rua, a calçada, os parques e as praças que foram tão idealizadas e objetivadas no urbanismo progressista acabam por perder sua essência. Para Sobarzo (2017, p. 198), "na perspectiva da rua [...] o espaço público "a partir do ideário do urbanismo progressista" passou a sofrer "um forte esvaziamento da vida, dos pedestres, e perde terreno para a circulação motorizada". Nas palavras de Sobarzo fica evidente a decadência do espaço público, mais precisamente aquele idealizado do ponto de vista urbanístico progressista. Corrente esta que reverenciou significantes projetos para praças e parques, no entanto, privilegiou a máquina, o automóvel, um dos principais agentes na decadência do espaço público da segunda metade do século XX.

Dessa forma, o privilegio atribuído ao automóvel, em conjunto com outros fatores (violência, baixa qualidade formal, funcional e estético) resultou em gradual abandono do espaço público urbano. Assim, os conflitos, o medo, a privatização e o abandono do espaço público são apontados como "a morte do espaço público". No entanto, para Caldeira (2000) e Sobarzo (2017) apenas houve uma transformação funcional e espacial, na qual atividades antes exercidas deixaram de ser praticadas, sendo substituídas por outras atividades. Diante disso, Caldeira (2000) crítica tal conceito, pois para o autor há uma metamorfose que, a partir da qual, as pessoas abandonaram as ruas, livre acesso, manifestações políticas, encontros, passando a evidenciar a desigualdade social.

Tal situação tem subestimado a importância socioespacial do espaço público urbano, resultando em seu esvaziamento, sendo que a qualidade estética-funcional tem sido vista pelos gestores públicos urbanos como problemática e custosa, "assim, muitas vezes o produzindo com seu programa funcional deficiente", (FRANCISCON, 2018, p.1). Dessa forma, o espaço público torna-se subutilizado, tanto em meio físico, quanto em simbólico, o espaço que deveria ser destinado às pessoas, a boa convivência, o local das práticas sociais, culturais, passa a ser opressor, passa a ser visto como peso morto e local do conflito. Diante de tal 
problemática, alguns arquitetos, urbanistas e teóricos apontam diretrizes para a melhoria dos espaços públicos atuais.

Para Gehl e Soholt (2009), o espaço público deve ser hierárquico, prevalecendo o fluxo de pessoas, ciclistas, transporte público e em último caso, veículos particulares (Figura 1).

Figura 1. Ideal hierarquia funcional no espaço público. Fonte: Gehl e Soholt (2009), adaptado pelos autores

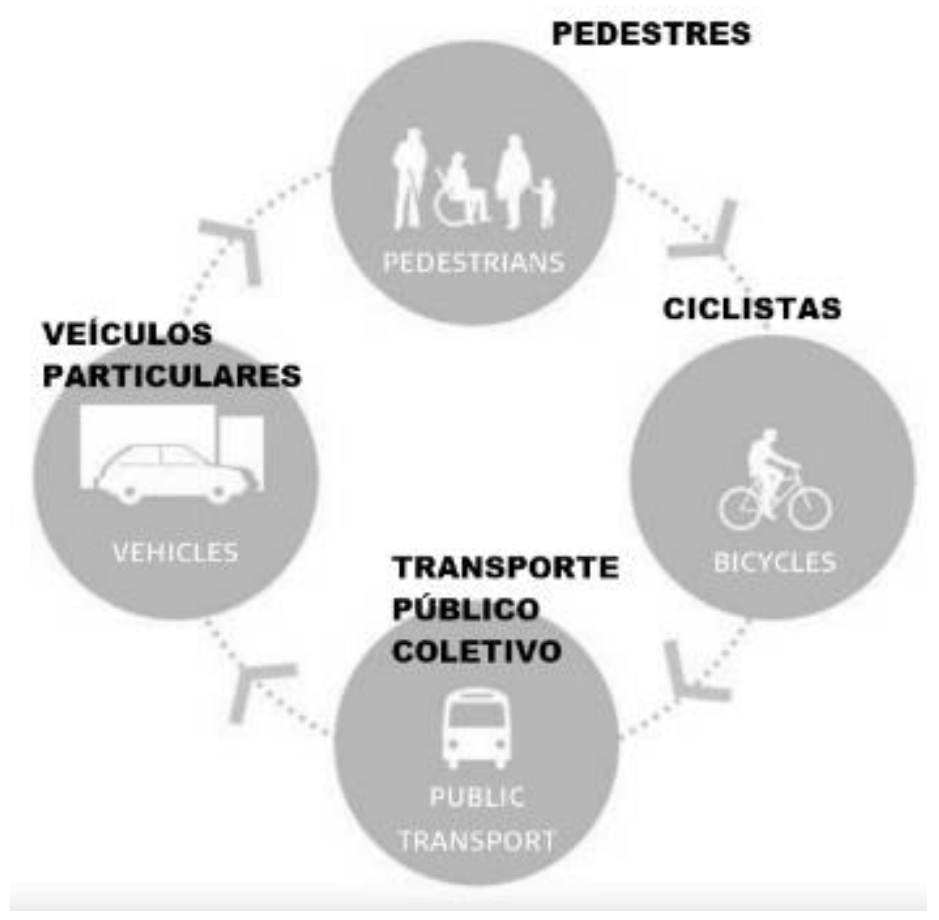

A figura 1 ilustra que há a necessidade de o espaço público ser mais humano, preservando a integridade de seus usuários, favorecendo a caminhabilidade (walkability), a conversação e a sociabilização. Para o deslocamento em ruas, avenidas, vias adjacentes, interiores de parques e praças dá se a prioridade a veículos de propulsão humana (bicicleta, patinetes, etc.) e coletivos, visto reduzir poluição (sonora e do ar), assim como, também, reduzir áreas destinadas a estacionamentos. Já os veículos particulares ocupam o mais desfavorável ponto hierárquico, na maioria das vezes, com as suas presenças indesejáveis.

Além do mais, na contemporaneidade a presença de qualquer veículo automotivo tem se mostrado desfavorável, causando conflitos (acidentes, poluição, redução da área peatonal). A presença dos automóveis, para autores como Jan Gehl $(2013,2016)$ tem resultado no princípio do desuso do espaço público. 
Assim, a diversidade, o respeito entre modais de locomoção, a socialização, a preservação ambiental e o urbanismo elegante e funcional (figura 2), juntamente com segurança, sustentabilidade, animação e salubridade (figura 3) são as principais características desejadas para o espaço público utópico.

Figura 2. Mudanças socioculturais e espaciais desejadas para o espaço público. Fonte: Organizado pelos autores

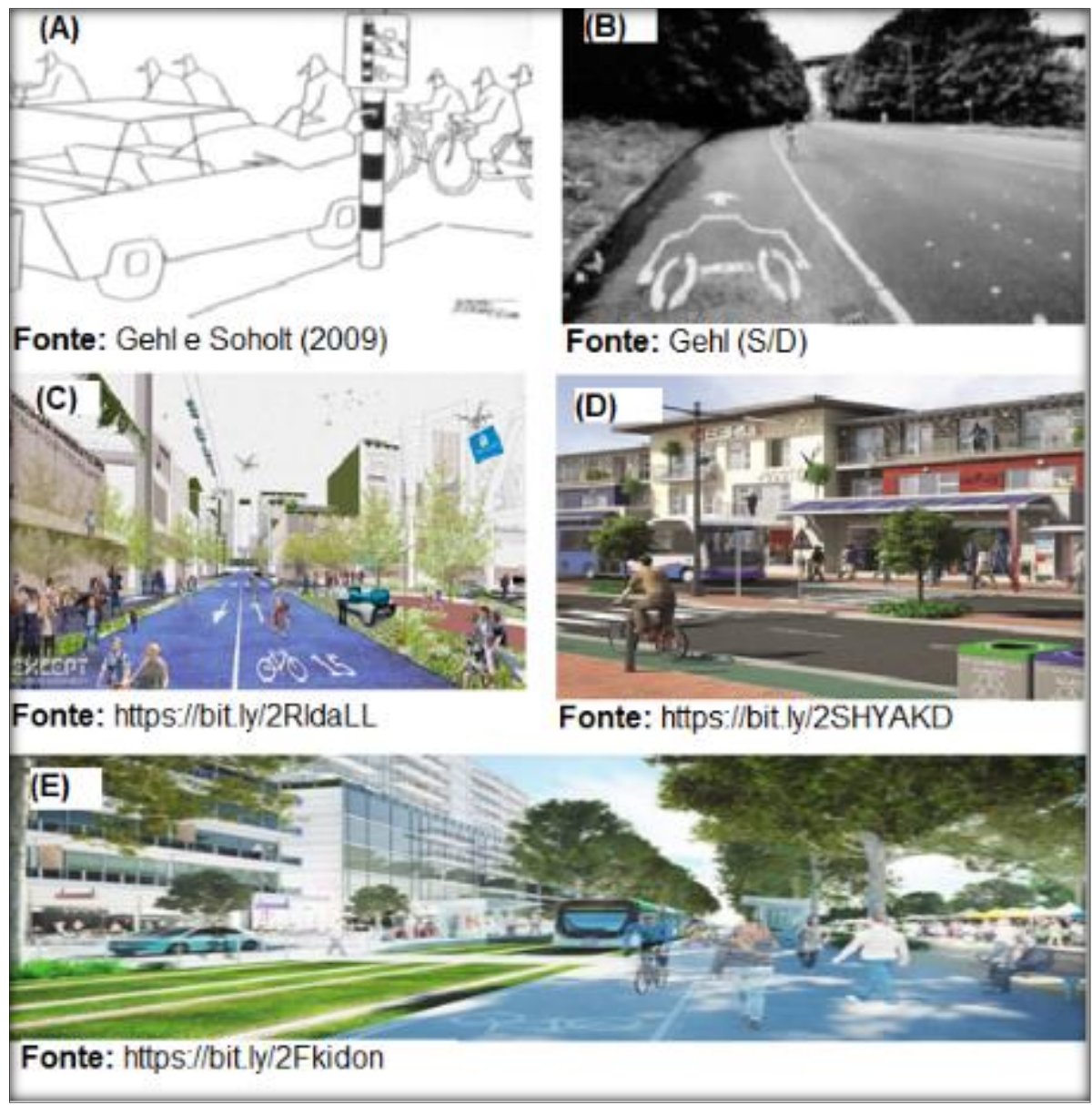

A figura 2 ilustra duas situações (A) e (B), as quais são bastante agressivas para os padrões culturais contemporâneos visto que essas situações caracterizam total inversão "de valores", uma vez que ciclistas e pedestres passam a ser protagonistas em vias e cruzamentos e aos veículos é atribuído papel secundário. Nos demais casos, (C, D e E), ilustram boa convivência entre modais de locomoção e pedestres. $A$ urbanização dotada de um design elegante, sofisticado e mútuo, também se faz presente no espaço público utópico. Destacamos o interesse no urbanismo elegante, sofisticado e mútuo, ou seja, focado no projeto e planejamento, envolvendo: harmonia entre materiais e formas geométricas e espaciais; diferentes modais de transportes e atividades recreativas e de contemplação, além da harmonia entre um elemento construído e o paisagismo. 
Figura 3. Dimensões do espaço público. Fonte: Gehl e Soholt (2009). Adaptado pelo autor

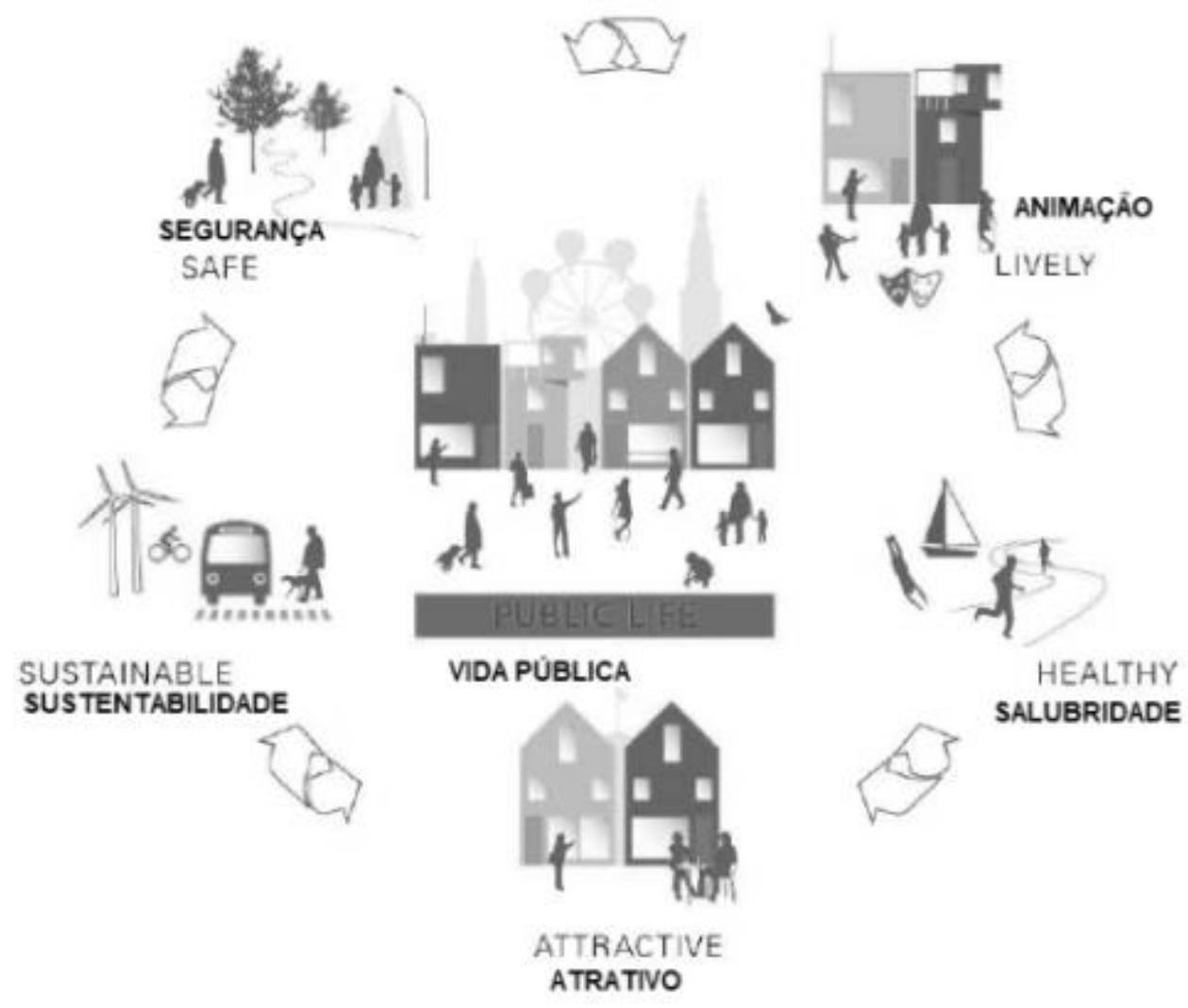

Assim sendo, a vida pública no espaço público ideal consiste numa rede integrada, constituída de inúmeros fatores que contribuem para a qualidade do espaço público. Por conseguinte, a figura 3 ilustra a relação do espaço público/vida pública com outras condicionantes. Assim, o bom espaço público deve contemplar: segurança, sustentabilidade, atratividade, salubridade e animação. Dessa forma, quando esses elementos estão presentes, o espaço é tratado como potencial.

É nesse contexto que o espaço público é feito por pessoas para pessoas, todos podem e devem trazer contribuições significativas, ou seja, é uma junção entre sociedade, poder público e frequentadores. O espaço público utópico preza pelo respeito entre usuários, pela boa convivência e por sua dinamicidade. Essa relação mútua é ilustrada na figura 4.

Figura 4. integração social desejada no espaço público utópico. Fonte: Gehl e Soholt (2009), tradução nossa 

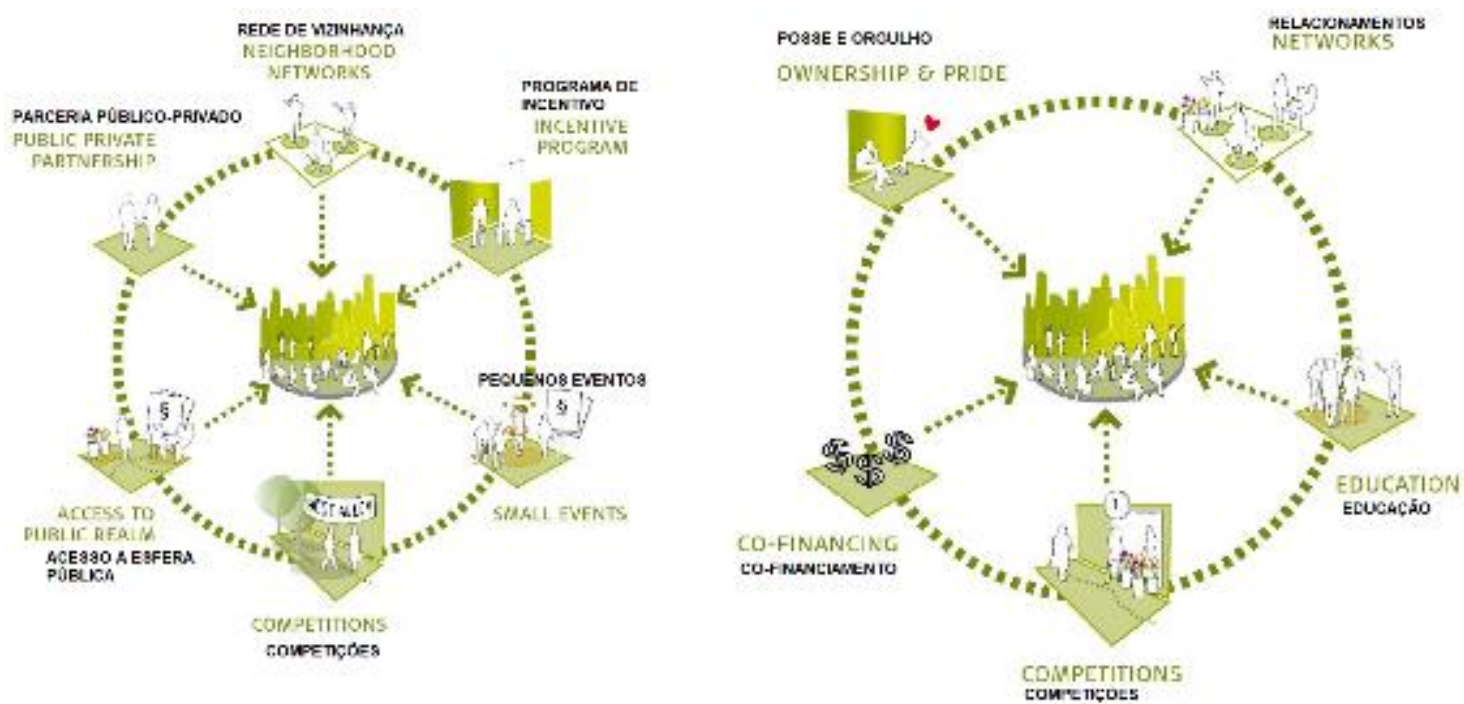

A figura 4, segundo Gehl e Soholt (2009) descrevem:

- Apoiar redes de vizinhança: fornecer condições para o início de rede de vizinhanças, sociocultural e rede de conhecimento.

- Iniciar programas de incentivo, ou seja, reduções de impostos ou mudança de legislação para garantir iniciativas e desenvolvimentos específicos no centro da cidade.

- Incentivar empreiteiros e gestor público local a se engajar em parcerias público-privadas para garantir o envolvimento e a apropriação das comunidades.

- Acesso à vida pública: flexibilizar legislação de modo que se permita a utilização das calçadas para lazer, comércio, parklets.

- Promover pequenos eventos - flexibilizando a legislação para que possam ocorrer no âmbito público.

- Incentivar competições entre vizinhos, premiando aquele que apresentar maior atratividade, como: melhor lazer, playground mais atraente, etc.

- Educação - trabalhe com os desenvolvedores para apoiar a colaboração no espaço público, reforce por que o espaço público é importante e como criar um bom espaço público; explorar a importância de uma fachada ativa, uso misto, etc.

- Incentivar o sentimento de posse e orgulho do espaço público.

- Incentivar a comunidade e empresas locais, desenvolvedores a cofinanciar novas áreas e redes envolvimento do setor público para garantir a boa qualidade. (GEHL E SOHOLT, 2009, p.126-127). Tradução nossa.

Destarte, a prioridade do espaço público utópico consiste no bem-estar humanitário, suas atividades cotidianas devem prevalecer em contraponto ao automóvel, o caminhar e demais atividades devem ser seguras, prazerosas e respeitosas.

Nesse mesmo sentido, conceitos de Banerjee (2001), Kent (2005) e Ghel (2016) ilustram as características desejadas nos espaços públicos atuais e futuros. Banerjee (2001, p.19) ilustra quase que perfeitamente nossa discussão teórica, caracterizando como importante ponto de vista acerca do espaço público utópico: "Concentre-se no conceito de vida pública em vez de espaços públicos", ou seja, o espaço público deve privilegiar a vida pública, deve servir como palco para as atividades humanas" (tradução nossa). No entanto, acrescentamos que o espaço não é apenas palco das ações humanas, mas é também condicionante delas. Dessa forma, o espaço abriga e interfere nas ações humanas, portanto sendo 
indissociáveis entre si, segundo Carmona et al (2003), trata-se de um processo bidirecional, assim a sociedade idealiza os espaços na qual, ao mesmo tempo, os mesmos influenciam a sociedade.

Enquanto que para Gehl (2016, p. 19), o espaço público deve privilegiar primeiramente a vida humana, "primeiro a vida, depois espaços públicos, só então edifícios - o inverso nunca funciona". No mesmo sentido, Kent (2005) defende o planejamento de lugares e pessoas, privilegiando a relação entre os mesmos. "Se você planeja cidades para carros e tráfego, você recebe carros e tráfego. Se você planeja pessoas e lugares, você tem pessoas e lugares" - Kent (2005, p.1).

É importante salientar a necessidade de fazer com que o frequentador se sinta parte do espaço público, ou seja, o livre acesso, tanto simbólico quanto físico, o espaço público deve ser visto como um adicional na vida da sociedade e não mais um produto de troca (trocar dinheiro por lazer). Para Loboda (2008):

[...] intentamos compreender como o "cidadão" utiliza-se da cidade considerando as transformações históricas caracterizadas por Lefebvre (2001) pela supremacia do "valor de troca sobre o valor de uso". Nesse contexto, torna-se necessário pensar formas de utilização da cidade que não sejam aquelas submetidas exclusivamente à esfera das trocas, mas sim da gratuidade, da impessoalidade e do sentimento de pertença (LOBODA, 2008, p.60).

Dessa forma, entendemos a complexidade envoltória acerca do espaço público utópico. De caráter complexo, envolvendo diversos atores e agentes, torna-se necessário a elaboração de bons espaços públicos em seu caráter funcional e formal. A sociedade também deverá ser ativa nesse processo, devendo prevalecer a coexistência cultural e ambiental, enfim será necessária uma nova conscientização social.

\section{AS POSSIBILIDADES UTÓPICAS ATÉ O PRÓXIMO SÉCULO}

Dentre os objetivos específicos, procuramos discorrer acerca do utopismo aplicado ao espaço público na contemporaneidade e para o futuro, isto é, em curto, médio e longo prazos. Visto já haver práticas utópicas exequíveis na contemporaneidade, partimos para um debate acerca dos conceitos aplicados para os próximos cem anos, prazo considerado por levar em conta as propostas urbanísticas já desenvolvidas. Nem sempre plausíveis, em muitas ocasiões surgem ideais mais complexos e distantes culturalmente e materialmente da contemporaneidade. Nesse contexto, objetivamos apresentar concepções projetais desenvolvidas por escritórios de arquitetura, as quais visam trazer contribuições ao espaço público a curto e longo prazos.

A presença do automóvel, muito criticado por impactar o uso do espaço público, é defendida por Sisson (2017). No entanto, é imprescindível que haja mudanças em seu sistema de direção porque a direção humana seria substituída pela inteligência artificial. Carros autônomos (AV- Autonomous Vehicle) propiciariam uma harmônica convivência entre pedestres e automóveis, com exuberantes ruas utópicas sob frondosas sombras 
arbóreas, proporcionando o respeito múltiplo entre pedestres e demais veículos, sejam eles de propulsão humana ou mecânica (Figura 5).

Diante disso, Sisson (2017) apresenta conceitos defendidos pelo HOK - escritório global de design, arquitetura engenharia e planejamento, cujos conceitos visam substituir as largas pistas de rolamento por amplas calçadas, Jardins filtrantes, árvores frondosas e paisagismo exuberante, primando pela natureza e homem. Para os veículos autônomos prevalecem apenas um conjunto de pequenas trilhas. A natureza e a paisagem constituem o partido arquitetônico.

Figura 5. Transformação do espaço público com base em veículos autônomos. Fonte: Sisson (2017), adaptado pelos autores.
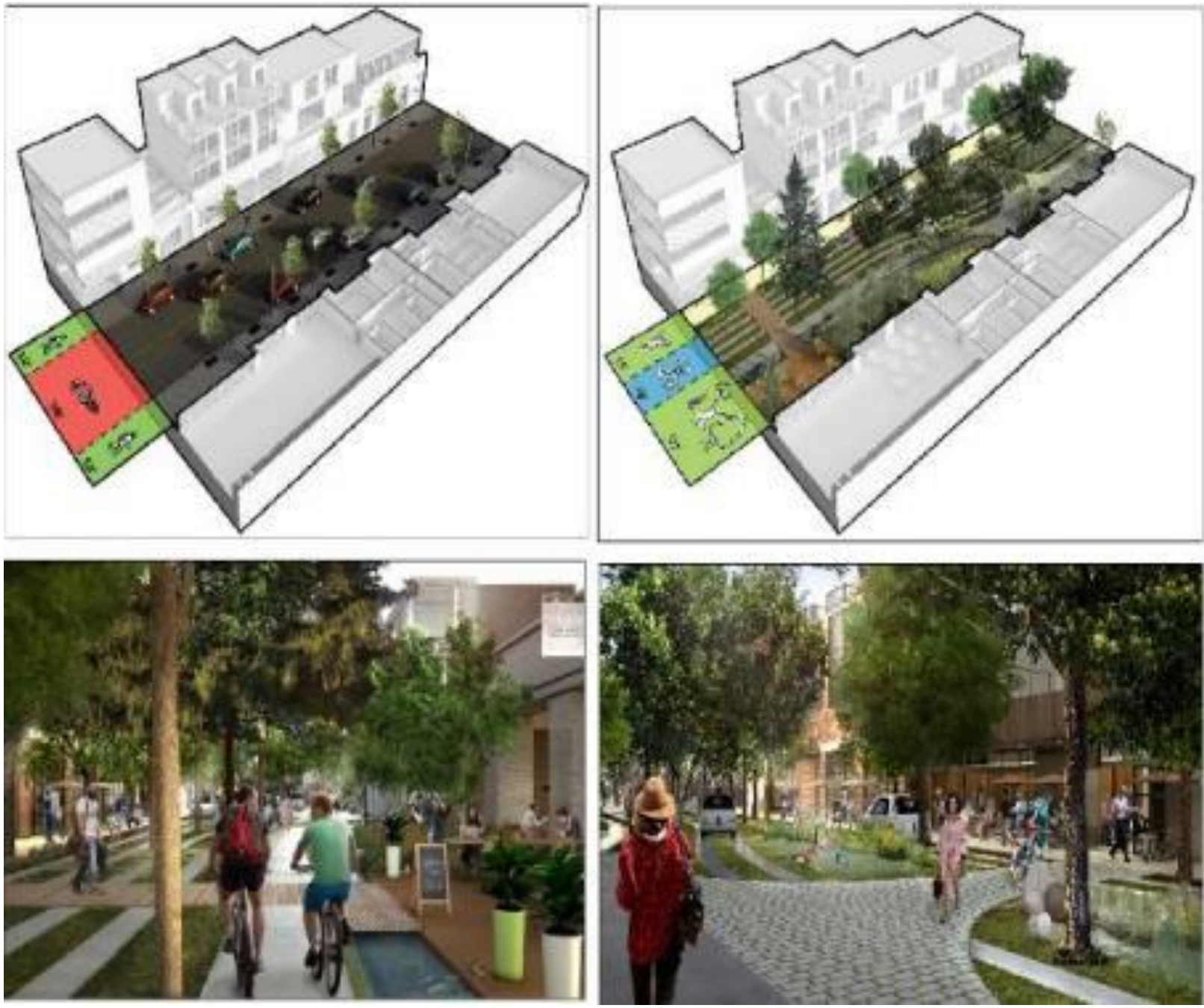

Mesmo subordinado à existência de veículos autônomos, é importante destacar possíveis restrições culturais. Inicialmente, é preciso convencer a população que espaços públicos devem ser projetados para pessoas, não mais para automóveis, "[...] Não gastamos tempo suficiente mostrando às pessoas como as cidades poderiam parecer se não fossem projetadas em função do carro". Fatores culturais são destacados 
como empecilho no desenvolvimento de novos projetos "Ainda não vimos este tipo de design porque os clientes não começaram a pensar assim" (SISSON, 2017, p.1), tradução nossa.

Davidson (2018), em seus estudos, pontua como será o futuro da rua atual ao caracterizar as ruas atuais de Nova lorque, pois as mesmas apresentam complexidade, sua superfície é responsável por conduzir e direcionar: veículos, pessoas e cargas; no subterrâneo portar sistema de: água potável e pluvial, esgoto, gás, eletricidade, etc. É uma máquina complexa, improvisada e maltratada, sendo considerado um sistema arcaico.

Segundo Davidson (2018), as ruas e demais espaços públicos têm seus usos e funções modificados com a evolução da sociedade. Portanto, é preciso prever as mudanças desejadas para o futuro. É importante destacar que, diferentemente do discorrido por Sisson (2017), Davidson acredita que os automóveis autônomos trarão transtornos à cidade contemporânea.

É importante salientar que a mobilidade urbana é fundamental no que tange aos aspectos relacionados ao fluxo de veículos, sendo preciso maximizá-lo e ao mesmo tempo, limitá-lo. Assim sendo, a melhoria na mobilidade urbana trará segurança, saúde às pessoas e lucratividade à cidade, visto eliminar tempo ocioso do trabalhador no interior de um veículo, conforme destaca Davidson (2018). A idealização da rua do futuro envolverá custos e mudanças culturais, no entanto trará recompensas (figura 6).

Figura 6. Perspectivas para a rua em 2030 ou mais. Fonte: Davidson (2018)

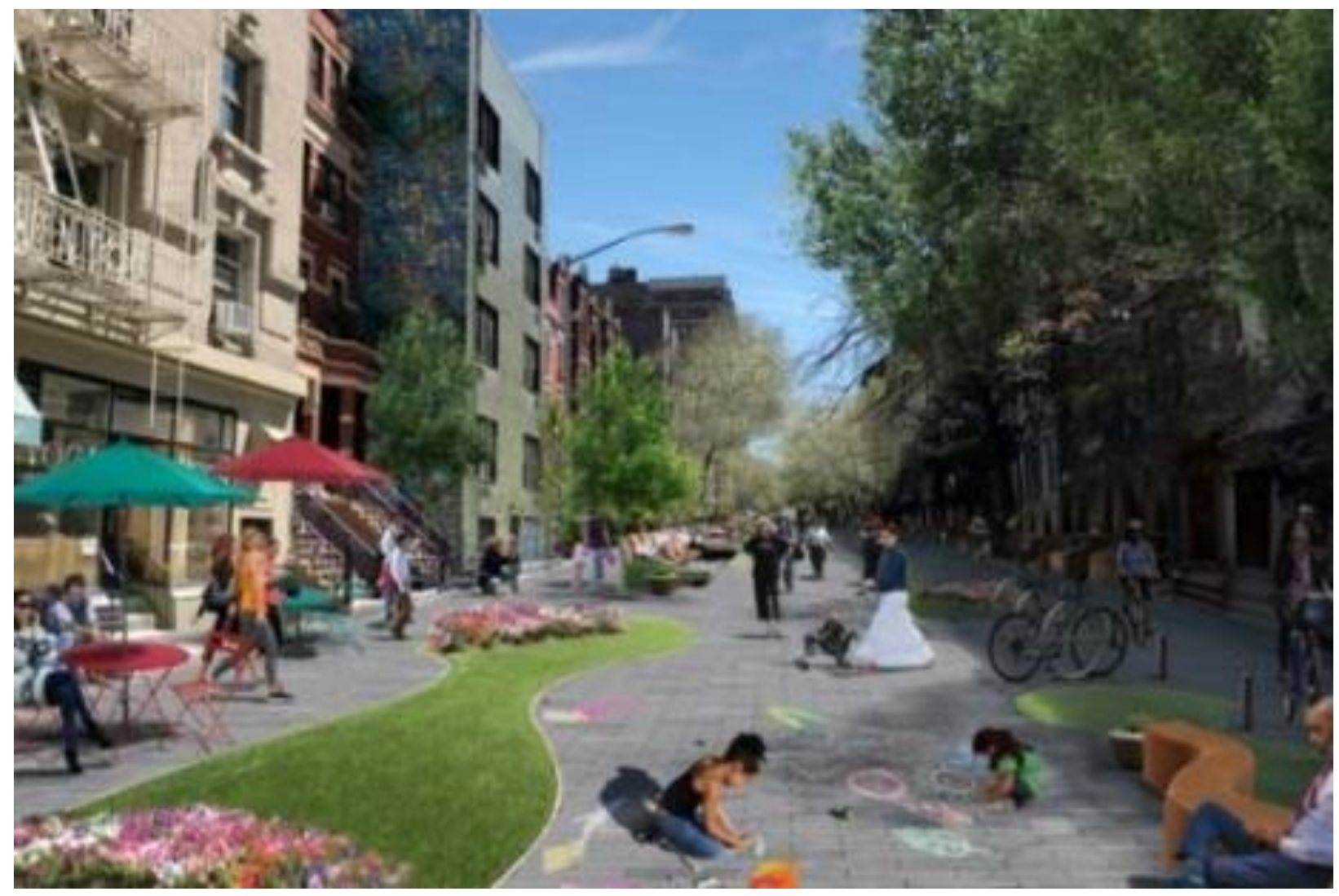


É notável na figura 6, a comunicação entre espaço público e privado (fachadas comerciais e residenciais). Portanto, há a necessidade da cidade e do espaço público se comunicarem com o seu entorno, principalmente com a cidade natural é destacada por Maki (2017).

A redução do fluxo de veículos e a criação de espaços públicos mais verdes são citados por Matthews (2010), quando apresenta o panorama proposto pelo time de arquitetos da Terreform e Michael Sorkin Studio para os arredores da ponte novaiorquina do Brooklyn ao fim dos próximos 20 anos, caso a cidade torne-se mais verde e menos dependente do automóvel (figura 7).

Figura 7: Arredores da ponte do Brooklyn em 2030. Fonte: Matthews (2010)

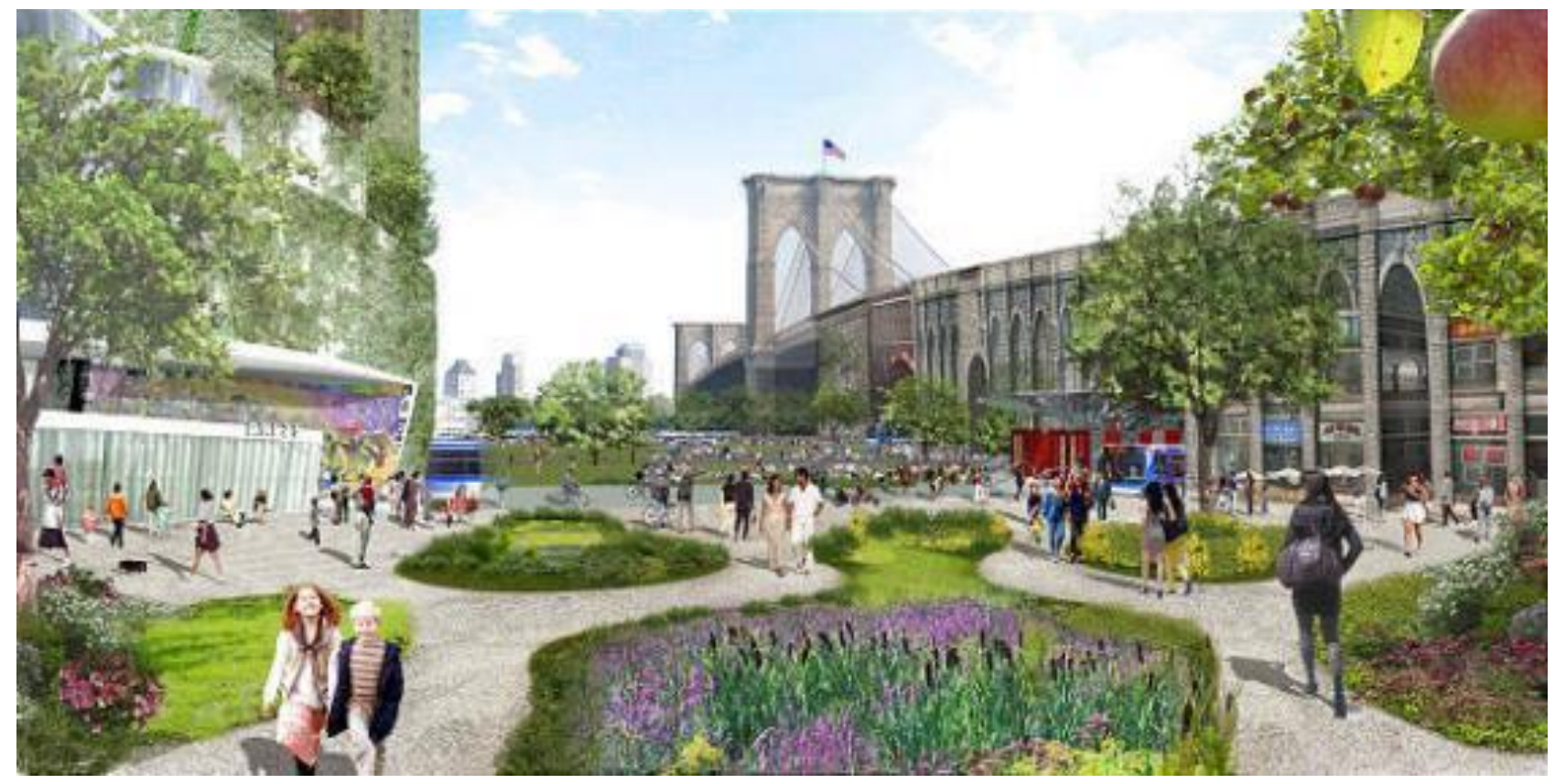

A cidade de Nova lorque mostra-se precursora em estudos relacionados ao espaço público do futuro, pois os estudos estão centrados em Michael Sorkin. Segundo Chin (2010), os projetos visam a aumentar a produtividade de alimentos nas cidades; fornecer soluções para a preservação de desastres e inundações e consequentemente transformar a cidade de Nova lorque em uma cidade eco-friendly.

Na cidade, segundo um plano mestre, estima-se haver uma autossuficiência urbana envolvendo: produção de alimentos, energia, resíduos, água, suprimento de ar e qualidade, fabricação, emprego, cultura, saúde e transporte (CHIN, 2010). A figura 8 estampa tais objetivos, ilustrando o panorama atual versus panorama futuro. 
Figura 8. Espaços públicos contemporâneos e no futuro. Fonte: Chin (2010), adaptado pelos autores

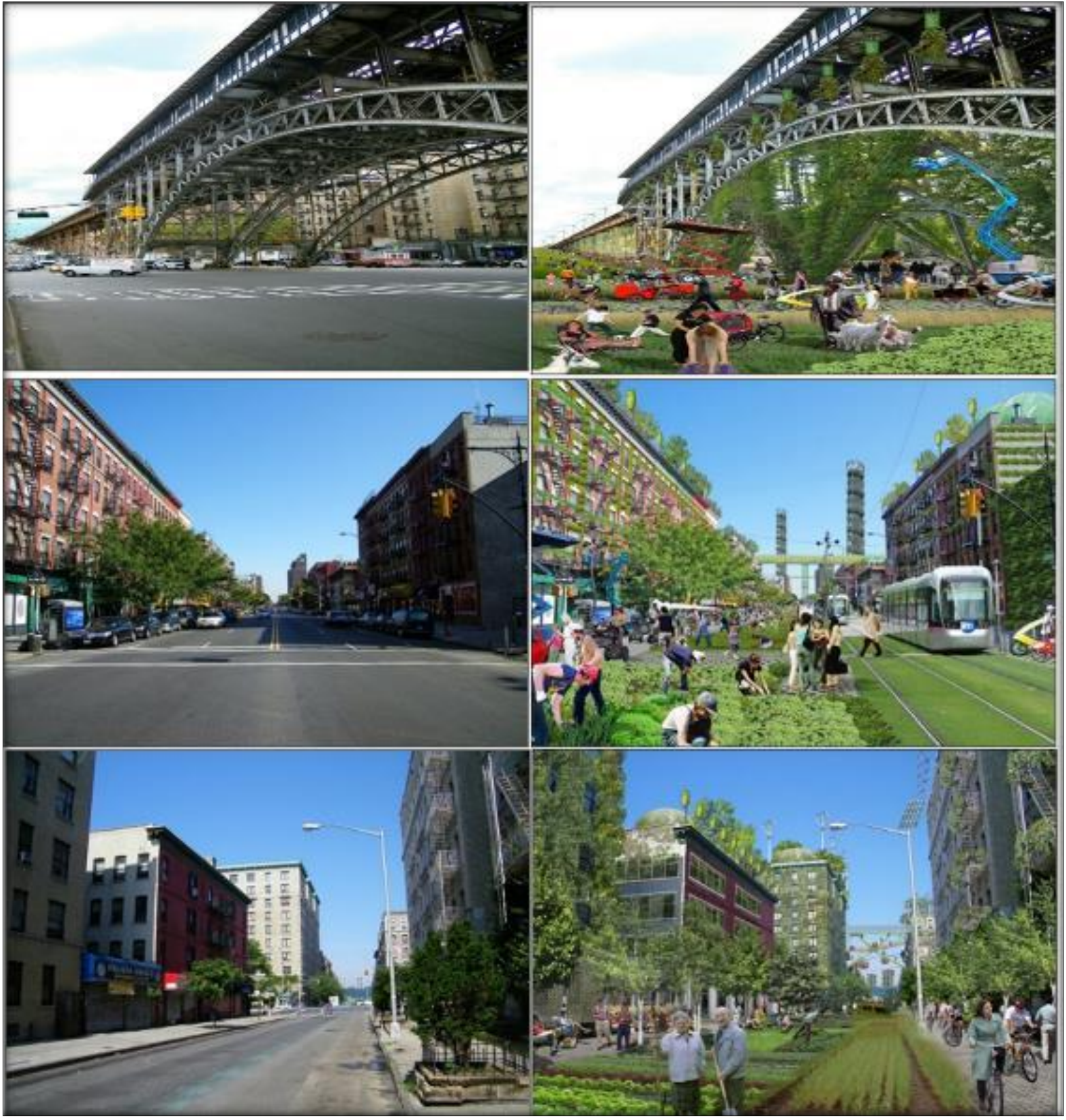

A Figura 8 ilustra a idealização futura para três espaços públicos atuais. O projeto visa retomar o contato do homem com a paisagem natural, assim como estimular a produção de alimentos em pleno espaço público. Nesse sentido, é importante destacar a coexistência entre humanos, vegetação e animais. Em todas as situações, o carro é relegado.

Além de veículos autônomos, a inteligência artificial é novamente condicionada ao urbanismo utópico nos conceitos de Carrigan et al (2016). Para os autores, cada vez mais os robôs tendem a assumir as atividades humanas. Dessa forma, além do progresso tecnológico da automação, restaria mais tempo aos humanos a se dedicarem a pesquisas científicas, artes e design. O grupo apresenta alguns estudos utópicos para 
determinados espaços públicos para o próximo século, mais precisamente em 2116 , ou seja, cem anos a partir da dada de elaboração da proposta (figura 9).

Figura 9. Projeções para o espaço público em 2116. Fonte: Carrigan et al (2016), adaptado pelo autor
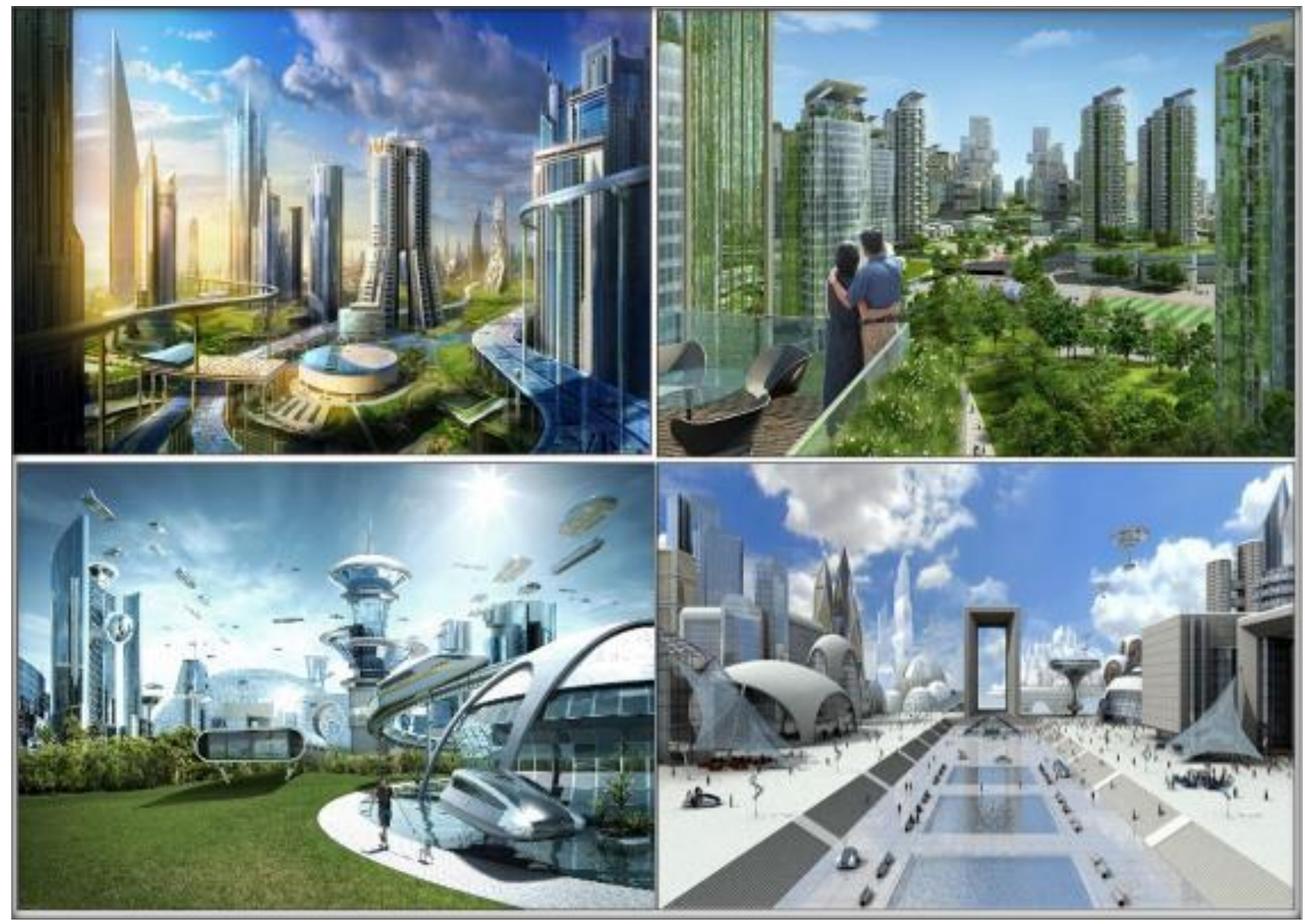

Conforme a figura 9, é relevante destacar a consideração de veículos voadores (que já vêm surgindo na atualidade por meio de drones). De forma geral, há um enfoque em uma arquitetura bastante futurística, com edifícios exuberantes mixados à densa vegetação. Vale salientar a consideração de um espaço público sem vegetação, opondo-se à tendência generalista do espaço público utópico, que na maioria das vezes, prima pelo retorno do homem à paisagem mais próxima do natural.

Em ambientes mais inóspitos, com a predominância de invernos rigorosos, como é o caso da cidade de Estocolmo na Suécia, o espaço público com setores cobertos e fechados é idealizado para o presente e o futuro (figura 10). Segundo Utopia Ideas (2017), objetiva-se criar um ambiente interno público para brincadeiras, socialização, contemplação e experiências culturais que podem ser usadas durante o ano todo. Trata-se de um parque comum, no entanto parcialmente coberto, nesse contexto o ambiente torna o parque atraente, principalmente no período frio e escuro do inverno. 
Figura 10. Espaços públicos cobertos visando à utilização durante todo o ano. Fonte: Utopia ideais (2017)

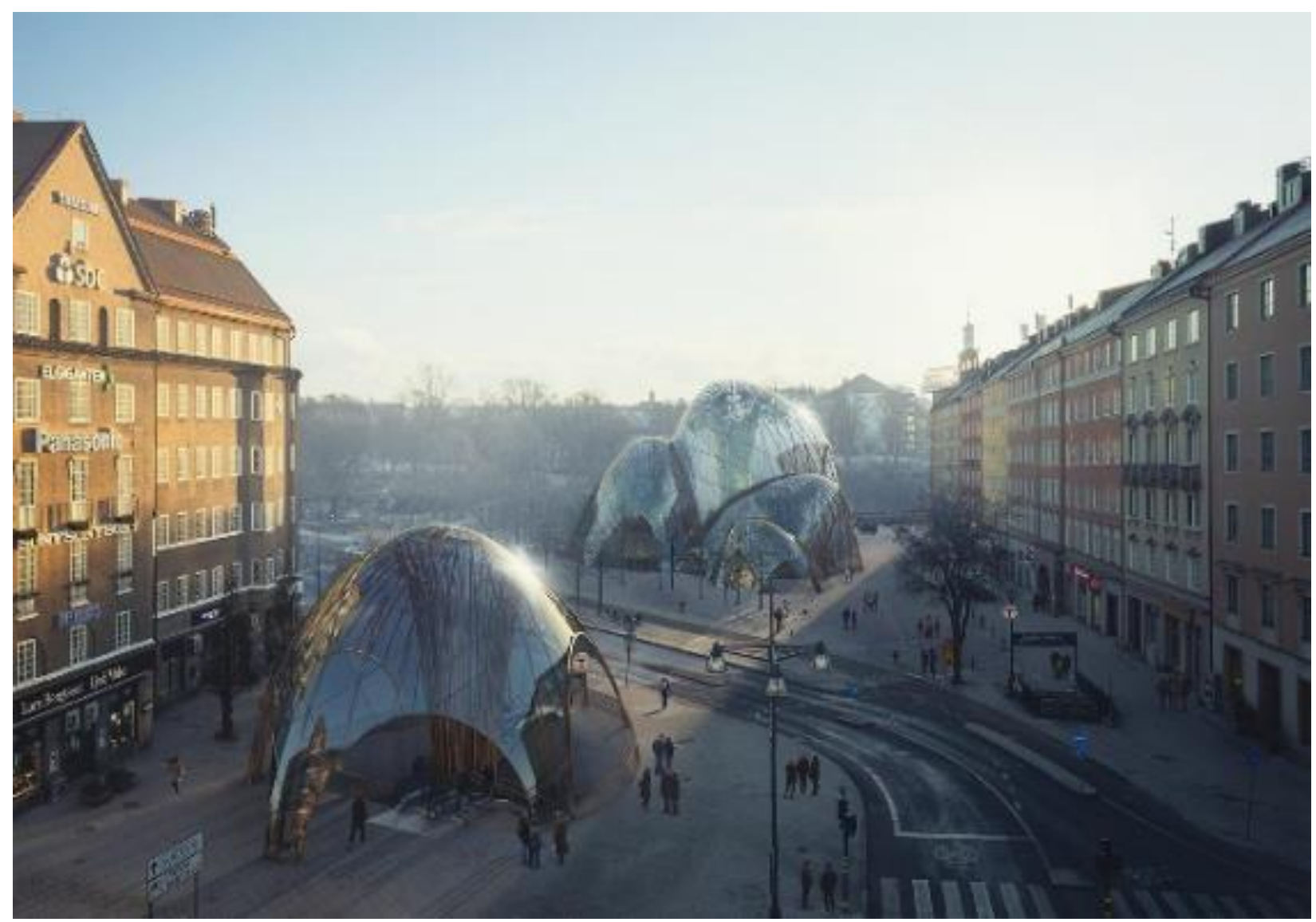

Com relação à natureza, inúmeros estudos demonstram os benefícios (emotivo e cognitivo) proporcionados ao humano,

Desde então, numerosos estudos mostraram que as pessoas se saem muito melhor, emocional e cognitivamente, em ambientes mais verdes do que em paisagens puramente urbanas. $E$, da perspectiva ambiental, ninguém duvida da necessidade de espaços mais verdes, desenvolvimentos mais inteligentes e fontes de energia mais limpas, (KONNIKOVA, 2015, p.1). (tradução nossa).

Diante do exposto, entendemos que a presença do automóvel é indesejada no espaço público, quando necessário, é preferível a utilização de veículos autônomos, coletivos e de baixo impacto ambiental. Além do mais, na maioria das vezes, o espaço público utópico prima pelo retorno do homem à paisagem natural (presença da fauna e flora), preza pela coexistência entre pessoas, animais, máquinas e vegetação.

Nesse contexto, entendemos que o espaço público utópico privilegia os princípios do bom espaço público que prezam por: significado, legibilidade, diversidade, escala humana, espírito de vizinhança e flexibilidade.

Notamos a presença marcante do significado do espaço público, quando as pessoas e famílias fazem do local um lugar que é, de alguma forma, a extensão de suas casas e expressam seus sentimentos por ele. À 
medida que as crianças brincam na rua, sob o olhar de seus pais, seus irmãos e amigos, à medida que as pessoas frequentam o local, fazem compras, sentem o prazer em permanecer, são características que fazem as pessoas se sentirem integrantes à paisagem, ao espaço ali presente. Também fica evidente a legibilidade, pois o espaço público utópico preza pela coexistência, seja entre pessoas e culturas e meio ambiente, ou por diferentes modais de transportes. A legibilidade é marcada pelas rotas definidas dos automóveis, pelo paisagismo e arquitetura definida por seus volumes e formas.

A diversidade funcional é marcante: o espaço público utópico oferta: lazer ativo (ciclismo, brincadeiras de criança), contemplativo (observação da paisagem, do entorno); lazer comercial (restaurantes, lanchonetes e lojas diversas). Bancos (para sentar) e proteções ambientais (abrigo do sol, chuva, frio, calor) são características voltadas à escala humana, ou seja, o ambiente feito para homens. Nesse contexto, o espaço público utópico preza pela escala humana.

O espírito de vizinhança é marcado pela integração entre espaço público e privado, a sintonia entre público e privado é marcante no espaço público utópico, na maioria das vezes torna-se imperceptível distinguir público do privado. Consequentemente, o privado torna-se uma extensão do público, que ao mesmo tempo, torna-se uma extensão do setor privado. Espaços livres (sem edificações) presentes nas figuras 6 a 9 demonstram a presença marcante da flexibilidade funcional, na ausência de uma estrutura definida (que dita as regras), pode se praticar a agricultura urbana, o lazer ativo, contemplativo, piqueniques, além de outras práticas sociais.

\section{CONSIDERAÇÕES FINAIS}

Dado por alguns autores como morto no final do século XX, o espaço público necessita-se reinventar, de forma a servir os anseios da sociedade contemporânea e futura. Com base na presente discussão teórica, consideramos que para se ter um bom espaço público com as características desejadas, é preciso que o mesmo desperte o desejo de permanência do usuário, oferecendo conforto, segurança, lazer e convívio social.

Ideais utópicos com bases aproximadas à nossa cultura vêm sendo implantados, sobretudo, visando privilegiar o homem em contraponto ao automóvel. Muitos dos citados ideais estão sendo implantados na contemporaneidade.

Ao longo da história, notamos diversos estudos focados na cidade como um todo. No entanto, pouco explorados quando direcionados apenas ao espaço público. Para o espaço público utópico, em longo prazo (10 anos - 100 anos), temos a ideia de um espaço, no qual deve predominar as coexistências: socioculturais, ambientais e modais de mobilidade (peatonal, bicicletas e automóveis. No momento, ao se tratar de espaços 
públicos, não há a consolidação de uma figura utopista. Entretanto, desponta as figuras atuantes de Mauro Calliari, Jan Gehl, Michael Sorkin, etc.

Isso posto, esse estudo aponta que o espaço público utópico demandará impactante mudança socioespacial em nossas cidades, considerando novas mobilidades, energias alternativas, recriação da paisagem primária e, principalmente, primar pela coexistência. Para tanto, a mudança mais radical e difícil para se implantar talvez ainda seja a aceitação cultural do respeito com o próximo e com meio ambiente em que vivemos.

\section{REFERÊNCIAS}

AGOSTINHO, Maria da Graça. Espaço público urbano e cidadania nas cidades contemporâneas: O caso do parque da luz em Florianópolis/SC. Tese doutorado. UFSC. Florianópolis. 2008. Disponível em: <https://bit.ly/2PTalYb>. Acesso em setembro de 2018.

ARGAN, Giulio Carlo. História da arte, como história da cidade. São Paulo: Martins Fontes, 1998.

BANERJEE, Tridib. The Future of Public Space: Beyond Invented Streets and Reinvented Places. APAjournal, Chicago, Vol. 67, No. 1. Winter 2001. Disponível em:< https://bit.ly/2QuapSQ >. Acesso em fevereiro de 2019.

BAUMAN, Zygmunt. Tempos líquidos. Rio de Janeiro: Editora Zahar, 2007.

BORTOLO, Carlos Alexandre de. O espaço público do parque do povo -Presidente Prudente SP: reflexões geográficas. Revista Geografia em Atos. Presidente Prudente, n. 13, v.1, p. 50-65, jan./jun., 2013. Disponível em: < https://bit.ly/2QsBeLW>. Acesso em dezembro de 2018.

BOYER, M. Cristine. The city of collective memory: its history, imagery and architectural entertainments. Cambridge MA, MIT Press. 1994.

CALDEIRA, Teresa Pires do Rio. Cidade de Muros: Crime, segregação e cidadania em São Paulo. São Paulo: Ed.34/Edusp, 2000.

CALLIARI, Mauro. Espaço público e urbanidade em São Paulo. São Paulo: BEl Comunicações, 2016.

CARMONA, Matthew; HEATH Tim; OC, Taner; TIESDELL, Steve. Public places, urban spaces: the dimensions of urban design. Londres: Architectural Press. 2003.

CARRIGAN, CONNOLLY, FABIAN, MCCARLIE, MCLEOD. Cross-discipline collaboration project influenced by speculative thinking and design ideas for a plausible hypothetical scenario set in the year 2116. Actuator Laboratories. 12/04/2016. Disponível em: < https://bit.ly/2Bc821r>. Acesso em janeiro de 2019.

CHIN, Andrea. michael sorkin: new york city (steady) state. Designboom. 15/07/2010. Disponível em: < https://bit.ly/20Qo2jK>. Acesso em agosto de 2019.

DARODA, Raquel Ferreira. As tecnologias e o espaço público da cidade contemporânea. Dissertação. Universidade Federal do Rio Grande do Sul. Porto Alegre, 2012. Disponível em:< https://bit.ly/2PQLWqq>. Acesso em dezembro de 2018.

DAVIDSON, Justin. What Is a City Street? And What Will It Become? The Intelligencer Feed. 18/01/2018. Disponível em: < https://nym.ag/2YWjisz>. Acesso em agosto de 2019.

FRANCISCON, Anderson. A importância da iluminação na vitalidade e mantimento do espaço público urbano. Anais do $\mathbf{X}$ CONCCEPAR. Campo Mourão, PR, 2019. Disponível em: <https://bit.ly/2Jylfls>. Acesso em agosto de 2019.

GEHL, Jan. Cycling and Global Responsibility. Founder of Gehl Architects. Handover to Seville, S/D. Disponível em: <https://bit.ly/2LNFNuW>. Acesso em fevereiro de 2019.

GEHL, Jan. Cidades para pessoas. 1. ed. São Paulo: Perspectiva, 2013. Acesso em dezembro de 2018. 
GEHL, Jan. A grande virada. Livreto. Fronteiras do Pensamento.Temporada 2016. Disponível em: < https://bit.ly/2QZLBHu >. Acesso em novembro de 2018.

GEHL, Jan; SOHOLT Helle Lis. Seattle - Public Space Public Life. International Sustainability Institute. 2009. Disponível em: < https://bit.ly/2HOkYOp>. Acesso em janeiro de 2019

INDOVINA, Francesco; O Espaço Público: Tópicos sobre a sua Mudança. In Cidades- Comunidades e Territórios. Dez. 2002, n.0 5, pp. 119-123. Disponível: < https://bit.ly/2QxAtBq>. Acesso em setembro de 2018.

INNERARITY, Daniel. A nova urbanidade. Jornal Arquitectos, n 231, p. 18-21. Publicação Trimestral da Ordem dos Arquitectos. Portugal. Abril - Junho. 2008.

JACOBS, Jane. Morte e vida de grandes cidades. São Paulo: Martins Fontes, 2014.

KONNIKOVA, Maria. How Green Could New York Be? The New Yorker.15/04/2015. Disponível: < https://bit.ly/2yOQc3R>. Acesso em agosto de 2019.

KENT, Fred. Streets are people places. Project for public Spaces. 2005. Disponível: <https://bit.ly/2D2t2tC $>$. Acesso em janeiro de 2019.

LE GOFF, Jacques. Por amor às cidades. São Paulo: Editora da Unesp, 1998.

LOBODA, Carlos Roberto. Práticas socioespaciais e espaços públicos em Guarapuava-PR. 2008. Tese (doutorado) - Universidade Estadual Paulista, Presidente Prudente. Disponível em: <https://bit.ly/2CkcwDU>. Acesso em fevereiro de 2019.

LYNCH, Kevin. A imagem da cidade. Trad. Maria Cristina Tavares Afonso. São Paulo: Martins Fontes, 2014.

MAKI, Fumihiko. Open space: utopia is not a building. Architectural Review. 17/03/2017. Disponível em: < https://bit.ly/33r1YPY>. Acesso em agosto de 2019.

MATTHEWS, Karen. NY exhibit imagines utopian, green cities in 2030. Deseret News. 24/06/2010. Disponível em: $<$ https://bit.ly/300ciwk>. Acesso em agosto de 2019.

NARCISO, Carla Alexandra Filipe. Espaço público: acção política e práticas de apropriação. Conceito e procedências. Revista Estudos e pesquisas em Psicologia, UERJ, RJ, ano 9, n.2, p.265-291, $2^{\circ}$ semestre de 2009. Disponível em <https://bit.ly/2fsylUf $>$. Acesso em dezembro de 2018.

SAMPAIO, Antonio Heliodório Lima. Cidade Ideal, Imaginação e Realidade. Revista de Urbanismo e Arquitetura, Salvador, v. 1, n. 6, p. 54-65, jul./dez. 1996. Disponível em:< https://bit.ly/2C9cFtL>. Acesso em janeiro de 2019.

SOBARZO, Oscar. Espaço Público. In Eliseu Savério Sposito, Org. Glossário de geografia humana e econômica. São Paulo: Editora Unesp, 2017. (187-201).

ROLNIK, Raquel. O que é cidade? São Paulo: Brasiliense, 2004.

SANTOS, Carlos Nelson Ferreira dos; VOGEL, Arno. Quando a rua vira casa: a apropriação de espaços de uso coletivo em um centro de bairro. Rio de Janeiro: FINEP/IBAM, Projeto, 1985.

SANTOS, Carlos Nelson Ferreira dos; VOGEL, Arno. Quando a rua vira casa: a apropriação de espaços de uso coletivo em um centro de bairro. Rio de Janeiro: FINEP/IBAM, Projeto, 1985.

SENNETT, Richard. Carne e pedra: o corpo e a cidade na civilização ocidental. 3. ed. Rio de Janeiro: Record, 2003. Disponível em: $<$ https://bit.ly/2LmUc0N>. Acesso em dezembro de 2018.

SERPA, Ângelo. O espaço público na cidade contemporânea. São Paulo: Editora Contexto. 2007.

SISSON, Patrick. Thanks to autonomous vehicles, we could have these utopian, tree-filled streets: An optimistic view of humancentered roadways in the age of driverless vehicles. Curbed. 30/11/2017. Disponivel em: $<$ https://bit.ly/2ikzYqY $>$. Acesso em agosto de 2019.

SOLÀ-MORALES, Ignasi. Territórios. Gustavo Gili, Barcelona. 2002.

TUAN, Yi-Fu. Paisagens do medo. São Paulo: Editora da UNESP, 2005. 
UTOPIA IDEAS. High quality non-commercial public space. The S: t Erik Indoor Park. 2017. Disponível em: < https://bit.ly/2uxIBmF>. Acesso em agosto de 2019.

WHYTE, William. The social life of small urban spaces. Nova York: Project for Public spaces, 2001, 2012. Disponível em: < https://bit.ly/2TjYN6X >. Acesso em dezembro de 2018. 